\title{
Prospective Teachers' Perspective on the Role of Instructor in Fostering Their Mathematical Disposition
}

\author{
Thesa Kandaga ${ }^{1,2^{*}}$, Rizky Rosjanuardi ${ }^{1}$, Dadang Juandi ${ }^{1}$ \\ ${ }^{1}$ Department of Mathematics Education, Universitas Pendidikan Indonesia \\ ${ }^{2}$ Department of Mathematics Education, Universitas Pasundan \\ *thesakandaga@unpas.ac.id
}

\begin{abstract}
Continuous treatment is needed in developing mathematical dispositions. Even at the higher education level, some prospective teachers still need proper treatment in developing their mathematical dispositions. This study tries to reveal instructors' role in fostering their students' mathematical disposition to better didactical situations. This study is qualitative research with a content analysis approach. The results obtained in this study indicate that the instructor's role is still needed in the classroom regardless of the students' mathematical disposition. Instructors ' expected learning role becomes diverse based on the mathematical disposition grouping between good, moderate, and less mathematical dispositions. For prospective teachers who have an excellent mathematical disposition, the instructor's role is to confirm a theorem, confirm answers to questions, and the benefits of contextual topics. For prospective teachers who have a satisfactory mathematical disposition, the instructor's role is to motivate, direct the learning, and keep the classroom conductivity. Whereas for prospective teachers deficient in mathematical disposition, the instructor's role is needed as a direct learning source, structured learning director, and an enjoyable learning rhythm.

Keywords: content analysis, mathematical disposition, prospective teacher, role of instructors'
\end{abstract}

Received: March 25, 2021 / Accepted: May 2, 2021 / Published Online: July 15, 2021

\section{Introduction}

Teaching is a duty that consists of multidimensional aspects (Mahoney \& Choe, 2016), especially in teaching mathematics and science (Maass et al., 2019). Similar to the other jobs, experience in teaching is as valuable as learning theories. Therefore, seeing and feeling directly a professional doing teaching is necessary for prospective teachers. Their perspective on an instructor's role when they are still college students will be remembered until later, and they play that role. As Dale (2010) said about his professor, who has the slogan "we teach who we are." They will remember the techniques and abilities that must be developed for individual students.

One of the most important aspects that should be developed in each learning is a mathematical disposition (Katz, 1993; NCTM, 2000; 1989). However, fostering this disposition requires time and discipline to maintain continuity, as Buss \& Craik (1983) stated, stating that dispositions are summarized of act frequencies. One or two treatments from instructors might 
indicate students' mathematical disposition. Unfortunately, students began to return to their old trends without continual repetition.

There is no precise number of repeated acts of frequency or observation period to conclude a disposition. Therefore, to say "Mary is persistent," one must contrast Mary to another person, and one must be able to provide evidence of the manifestations for a while until it depicts the fact (Buss \& Craik, 1983). Although it is challenging to determine the treatment period, ideally, we should provide appropriate treatment for each student continuously. Therefore, knowing each student's exact needs will enable the instructors to maintain treatment continuity throughout the learning process. Of course, realistically, it is challenging to meet the needs of every student. Nevertheless, knowing students' perspectives on what they need in learning will be invaluable for each instructor in designing their learning whenever it has to choose.

This study aims to reveal the expectations of prospective teachers to the instructors in classroom learning. Perspective from the prospective teacher is needed in fostering mathematical disposition. It is a shortcut that provides information for instructors about the expected treatment and provides opportunities for prospective teachers to discuss issues in learning that they will face in the future. Moreover, these self-description results will indicate that they are aware of such factors. This awareness is required as Dale (2010) and Collinson (1996) revealed that it is essential for prospective teachers to have intrapersonal knowledge before delivering it to them their students. Also, teachers with good dispositions will foster a good disposition towards their students (Osguthorpe, 2008).

\section{Methods}

\section{Data Collection Technique}

This research was conducted with a qualitative approach and divided into two phases. An individual interview method was conducted in the first phase to gain information regarding participants' mathematical dispositions. Knodel (1993) and Morgan (1998) mentioned that individual interviews allowing the researcher to probe participants' attitudes, beliefs, desires, and experiences to get a deeper understanding. That natural behavior of the method is ventured a better fit in collecting participants disposition other than the standard Indonesian questionnaire method.

Six participants who previously volunteered were selected purposively by the researcher. The selection criteria are needed to be vocal in their opinion and the researcher's subjective criteria regarding the possibility of their mathematical disposition. This is intended to speed up 
the research process. Where participants who are vocal in their opinion can open various inputs, and subjective selection is carried out by considering the representation of each mathematical disposition criterion.

A scripted question in individual interviews in the first phase is used to assess participants' mathematical dispositions. These questions are based on NCTM indicators (1989: 233) adapted to be naturally shorter and adjusted to participant responses. For example, indicators of flexibility in finding alternative problem-solving methods, along with indicators of persistence in solving problems, and indicators of interest in mathematics are summarized in the question "Is mathematics difficult?". Of course, then proceed with a variety of questions that are tailored to the participant's responses.

The second phase method was a focus group with 6 participants. All participants in this phase have been interviewed individually, and their mathematical disposition has been identified. The focus group method in this study aims to gain an in-depth understanding of social issues. Participants' reactions to specific researcher-posed questions are studied. The group shares their feedback, opinions, knowledge, and insights about various things the instructors should do in learning.

\section{Data Analysis Technique}

The data obtained from individual interviews and focus groups were then analyzed qualitatively. According to Leech and Onwuegbuzie (2007, 2008), qualitative analysis techniques can be used to analyze focus group data. Individual interview data is accomplished in two stages. In the first stage, the researcher draws relationships and identifies keywords used by respondents. In the second stage, the researcher eliminates, combines, or subdivides the coding categories identified in the first step until certain participants can be assigned to a mathematical disposition criterion.

Meanwhile, the data obtained from the focus group phase were analyzed by content analysis as recommended by Morgan (1988). This research content analysis enables a systematic coding of data by organizing the information into categories to discover patterns undetectable by merely listening to the tapes or reading the transcripts (Robson, 1993; Yin, 1989). The analysis also includes simple, grounded theory analysis (Charmaz, 2006; Glaser, 1978, 1992; Glaser \& Strauss, 1967, Strauss, 1987). 


\section{Results}

Based on participant responses, three participants fulfilled all the NCTM's (1989) mathematical disposition; one participant fulfilled most of these indicators, while two participants fulfilled only a tiny portion of these indicators. In the discussion, participants were divided into categories based on short responses from participant identification as follows.

Table 1. Participant identification results

\begin{tabular}{lcc}
\hline $\begin{array}{c}\text { Response to the Mathematical } \\
\text { Disposition indicator }\end{array}$ & $\begin{array}{c}\text { The Mathematical } \\
\text { Disposition Category* }\end{array}$ & $\begin{array}{c}\text { Number of } \\
\text { Participants }\end{array}$ \\
\hline All fulfilled & Good & 3 \\
Mostly fulfilled & Satisfactory & 1 \\
A small portion fulfilled & Deficient & 2 \\
\hline * made by researchers to ease the mention & &
\end{tabular}

\section{Findings from Participants Who were Categorized as Deficient in Mathematical Disposition}

Participants who are categorized as deficient in mathematical disposition fail to meet most of the indicators proposed by NCTM (1989). One such indicator is an appreciation of mathematics. In this indicator, a noticeable difference can be seen. As prospective mathematics teachers, Deficient Participants understand the role of mathematics in everyday life. However, this understanding is still too general, not essential, and they are confused when confronted further. Following are a few snippets from individual interviews of deficient participants.

Table 2. Deficient participant 1 individual interview excerpt

\begin{tabular}{cl}
\hline \multicolumn{1}{c}{ Questions } & \multicolumn{1}{c}{ Deficient Participants 1 } \\
\hline What do you think mathematics is? & $\begin{array}{l}\text { Mathematics is about calculating; it must be } \\
\text { in everyday life. Indeed, in life, there must be } \\
\text { mathematics, counting money, for example. }\end{array}$
\end{tabular}

Can you give an example other than to count When looking at the clock, there is a lot of money? numbers or symbols. If someone does not know (what symbol it is), maybe he/she cannot know what it means.

Are there topics in mathematics that do not Um, there is, but I guess that remains the do calculations? basis for calculating too.

Although the participants have entered their third year in college majoring in mathematics education, they still appreciate mathematics to calculate everyday logic.

The topic and type of mathematical problems often determine the participants' interest in mathematics. There is no effort, perseverance, interest, or confidence in solving various mathematics challenges, as the following interview excerpt with another deficient participant. 
Table 3. Deficient participant 2 individual interview excerpt

\begin{tabular}{|c|c|}
\hline Questions & Deficient Participants 2 \\
\hline $\begin{array}{l}\text { Have you ever felt excited to solve } \\
\text { mathematics problems? }\end{array}$ & $\begin{array}{l}\text { I did, (but) it happened when the question and } \\
\text { the material were easy, and the problem was } \\
\text { also the same as the example, so I had the } \\
\text { urge. 'Ah, it is the same ...'. (Finally) I worked } \\
\text { on it and was able to finish it. However, when } \\
\text { even an example seems complicated, I am } \\
\text { lazy to search, lazy to explore further what } \\
\text { has been given by the instructor. When the } \\
\text { problem is different from the example, it is } \\
\text { hard for me, sir. }\end{array}$ \\
\hline
\end{tabular}

Based on the excerpt from the interview above, it seems clear that both participants have problems in their disposition to mathematics. This situation is unique because they are prospective mathematics teachers. It turns out that after further exploration, mathematics education majors are indeed not their first choice for college. Another unique about one of the deficient participants was that he was not worried about what happened in the classroom. After further exploration, it is not a form of confidence but more likely a resignation to the circumstances.

The second phase for both deficient participants shows that the instructor has a central role in fostering their classroom interest. They also hope that the instructor can develop a sufficient learning flow for them. Following are the responses of the two deficient participants in the focus group discussion on the instructor's role for them.

Table 4. Focus group discussion excerpt with deficient participants

\begin{tabular}{|c|c|c|}
\hline Questions & Deficient Participants 1 & Deficient Participants 2 \\
\hline $\begin{array}{l}\text { What kind of learning model } \\
\text { do you prefer in class? }\end{array}$ & $\begin{array}{l}\text { I prefer the instructor who } \\
\text { explained it, sir. (Prefer lecture } \\
\text { or direct models). Especially } \\
\text { when it comes to group } \\
\text { presentations (I do not like it), } \\
\text { sir, we have to filter the } \\
\text { knowledge from these people } \\
\text { sometimes, not necessarily } \\
\text { correct. }\end{array}$ & $\begin{array}{l}\text { Yeah, we have to } \\
\text { reexplore the subjects. It is } \\
\text { a waste of time for us. } \\
\text { Why not just say it directly } \\
\text { by the instructor, and we } \\
\text { just need to follow? }\end{array}$ \\
\hline $\begin{array}{l}\text { I will write it down. Do you } \\
\text { have other suggestions on } \\
\text { what the instructor can do to } \\
\text { help you to understand a } \\
\text { topic? }\end{array}$ & $\begin{array}{l}\text { That depends on the instructor. } \\
\text { Can the instructor master the } \\
\text { class? If the instructor is able, } \\
\text { we will also enjoy it. In the } \\
\text { class, it is not just talking with } \\
\text { no interaction with the } \\
\text { students, flat, just listening to } \\
\text { it, it will be boring, no }\end{array}$ & $\begin{array}{l}\text { I hope the instructor can } \\
\text { explain a topic with fun. } \\
\text { He explained until I } \\
\text { understood and was able to } \\
\text { solve the problem. Then } \\
\text { the topic is given in the } \\
\text { exam. That helped me. }\end{array}$ \\
\hline
\end{tabular}




\begin{tabular}{lll}
\hline \multicolumn{1}{c}{ Questions } & \multicolumn{1}{c}{ Deficient Participants 1 } & Deficient Participants 2 \\
\hline & $\begin{array}{l}\text { intermezzo. (Intermezzo) is a } \\
\text { must, so that the class is not } \\
\text { boring. Otherwise, the students } \\
\text { will play on their cellphones or } \\
\text { maybe sleep. }\end{array}$ \\
\hline $\begin{array}{l}\text { Okay, now we are talking } \\
\text { about the class, your friends. }\end{array}$ & $\begin{array}{l}\text { By following "the path" that is (showing a gesture that he } \\
\text { formed in the class. For agrees) }\end{array}$ \\
$\begin{array}{l}\text { In your perspective, how can } \\
\text { an instructor create an ample, if a student looks } \\
\text { effective classroom } \\
\text { atmosphere for learning? }\end{array}$ & $\begin{array}{l}\text { bored, the instructor can dilute } \\
\text { (the atmosphere) with a variety } \\
\text { of tricks to focus more on him }\end{array}$ \\
\hline
\end{tabular}

As we can conclude, deficient participants need more special treatment than participants in the Satisfactory and Good categories. Such special treatment can foster their interest in the topic and foster respect for the instructor. One that should underline is the desire of deficient participants to be explained with the direct learning model. However, their desire to get a lecture or direct learning model is undoubtedly rather odd. Student-centered learning models should foster interest, confidence, and meaningful learning regardless of their Mathematical Disposition (Handelsman et al., 2004; McCombs \& Whistler, 1997; TEAL, 2010; Froyd \& Simpson, 2008). A little opinion from researchers is that they did not get the student-centered learning model correctly and adequately. Of course, this opinion requires in-depth research to prove the truth.

For this research, we can conclude that instructors play a role in fostering this Deficient Participants interest in a topic. Instructors also play a role in putting pressure to have persistence, determination, and encouragement to learn. This role is implicit in their desire to ask instructors to provide a direct learning model.

\section{Findings from Participants Who were Categorized as Satisfactory in Mathematical} Disposition

In participants categorized as satisfactory in mathematical disposition, several mathematical disposition indicators seemed to have been fulfilled. Although participants still assume that the essence of mathematics is a calculation, with all of their arguments. However, there is still a bit of appreciation for the essence of mathematics learning. Unlike participants in the deficient category, satisfactory participants have a high level of determination and interest in mathematics. 
Table 5. Satisfactory participant's interview excerpt

\section{Questions}

\section{Satisfactory Participant}

Do you think that mathematics is a difficult You say it is difficult, many people say it is topic? difficult, I agree it is difficult. But because it is difficult, it makes me curious about the problem.

Could you tell me why?

I felt pleasures and pride when solving the problems.

Satisfactory participants showed flexibility and reflection in solving mathematical problems.

However, he also revealed inconsistencies in his perseverance, as in the following interview excerpt.

Table 6. Satisfactory participant's lacks of perseverance

\section{Questions Satisfactory Participant}

Have there been any problems that you did Yes, sometimes, sir. But when it comes, I not find the solution to? If so, what do you used to look for various ways from another do? source.

That is good. Have you ever searched for Honestly, sir, I never relearn what I got in some mathematics topics without being given college unless there was an assignment, homework or a problem by the instructors? homework, or exam.

From the snippets of the above conversation, it is not surprising that for participants categorized as satisfactory, the instructor's role is quite apparent. One of the roles that implicitly emerged based on the individual interview was as a motivator and director for learning. Participants also expressed this in the focus group discussion.

Table 7. Focus group discussion excerpt with satisfactory participant

\begin{tabular}{ll}
\hline \multicolumn{1}{c}{ Questions } & \multicolumn{1}{c}{ Satisfactory Participant } \\
\hline $\begin{array}{l}\text { Which one do you think is better, studying at } \\
\text { home (alone) or with the class (also the } \\
\text { instructor)? }\end{array}$ & $\begin{array}{l}\text { I prefer to attend classes. Some instructors } \\
\text { guide the learning. But of course, they must } \\
\text { have the knowledge and good methods to } \\
\text { make me understand, or the situation will be } \\
\text { the same (at home or with the class) }\end{array}$ \\
\hline Do you enjoy it (the classroom learning)? & $\begin{array}{l}\text { That depends on the teacher in mastering the } \\
\text { class. The classroom situation is not } \\
\text { conducive for learning when the instructor is } \\
\text { not able to master the class. The students start } \\
\text { playing on their cellphones, or the worst is } \\
\text { they have their conversation. It will disturb } \\
\text { other students who want to listen. }\end{array}$ \\
\hline
\end{tabular}

Satisfactory participants can rarely learn independently outside the classroom, and they rely on learning in the classroom to improve their understanding. The instructor's role in developing learning to be more exciting and enjoyable is important for participants' understanding. According to satisfactory participants, instructors play a role in determining the flow of learning 
in the classroom, determining their interests, and providing excellent and practical understanding. According to participants, there is no apparent inclination towards a particular learning model. However, according to participants, valuable and effective learning is when they can engage in interaction, foster interest in the topic, and there is little intermezzo.

\section{Findings from Participants Who were Categorized as Good in Mathematical Disposition}

Based on individual interviews, there are three participants whose mathematical disposition can be classified into Good Category. All three showed a very high enthusiasm for mathematics. These Well categorized participants like challenges and continuing to explore knowledge, and it has become their daily life. There was a doubt about one participant who formerly did not show his persistence in mathematics, so that the participant was categorized as a Satisfactory participant. However, after further investigation, he has such a busy schedule as a social activist. Those prompted us to ignore these indicators and focus on other indicators of mathematical disposition. A satisfying one is that all good participants have understood that doing the calculation is not sufficient in mathematics learning, but critical and systematic thinking is a must in mathematics learning, as stated by Harel (2008a; 2008b).

Good Participants want a quiet classroom atmosphere, effective learning, and focus. They tend to be independent and have good self-efficacy. The following excerpt in Table 8 is from the focus group discussion regarding their perspective of instructors' roles. Before this snippet, all three have always been verified to study independently other than in class. Each participant is marked with a number.

Table 8. Focus group discussion excerpt with good participant

\begin{tabular}{llll}
\hline Questions & Good Participant 1 & Good Participant 2 & \multicolumn{1}{c}{$\begin{array}{c}\text { Good } \\
\text { Participant 3 }\end{array}$} \\
\hline $\begin{array}{l}\text { Which one do you think I prefer to study } \\
\text { is more effective, independently. Because }\end{array}$ study in more to discuss in \\
studying independently it will be more focused, focused because it class \\
or studying in class with with \\
and I can sort out suits the needs. But instructors' \\
between the parts that the explanation directions on a \\
have been mastered and from the class topic. Although \\
the parts I have to \\
deepen.
\end{tabular}




\begin{tabular}{|c|c|c|c|}
\hline Questions & Good Participant 1 & Good Participant 2 & $\begin{array}{c}\text { Good } \\
\text { Participant } 3\end{array}$ \\
\hline & & $\begin{array}{l}\text { class and later was } \\
\text { continued with } \\
\text { study } \\
\text { independently, and } \\
\text { it was effective. }\end{array}$ & $\begin{array}{l}\text { what I am doing } \\
\text { is right or wrong. }\end{array}$ \\
\hline $\begin{array}{l}\text { That is good. Knowing } \\
\text { your best own way is } \\
\text { already a good asset. } \\
\text { Now, is the class you } \\
\text { are in always as you } \\
\text { expect? Excuse me, of } \\
\text { course; nothing is } \\
\text { perfect. I mean, what } \\
\text { factors can make it as } \\
\text { effective as you want? }\end{array}$ & $\begin{array}{l}\text { Agree. The instructors } \\
\text { are very influential. } \\
\text { They must be able to } \\
\text { make the crowds quiet. } \\
\text { Assertiveness and traits } \\
\text { can create a comfortable } \\
\text { class for learning. }\end{array}$ & $\begin{array}{l}\text { Indeed, it is not } \\
\text { always effective. } \\
\text { Instructors are } \\
\text { influential, also the } \\
\text { course participants } \\
\text { and the condition of } \\
\text { the classroom. }\end{array}$ & $\begin{array}{l}\text { They are like a } \\
\text { director in the } \\
\text { class. They must } \\
\text { prepare a good } \\
\text { learning flow to } \\
\text { be presented and } \\
\text { followed. } \\
\text { Otherwise, it } \\
\text { would be messy. }\end{array}$ \\
\hline
\end{tabular}

From the snippet of the focus group discussion above, we can conclude that all three participants tend to be sensitive to learning conditions. They do not like distractions and understand their abilities and learning needs.

One of the roles of instructors for Good Participants is to provide a broader understanding of a topic. It means that instructors provide a good understanding of applying the topics to things they did not expect. It also means that understanding could come from within participants themselves to appreciate its use in everyday life. Therefore, assuming we drag this opinion into the mathematical disposition indicator, which NCTM (1989: 233) points out, we can say that the instructor has a role in fostering participants' appreciation of mathematics and providing an understanding of contextual mathematics problems.

Good Participants also consider instructors as partners to discuss, confirm a theorem, and confirm solutions to a problem. It shows that even though good participants have good abilities and confidence, they still need confirmation from others (in this case, the instructors). Confirmation from others can foster their confidence in communicating their ideas. This finding is also in line with what was stated in several other studies such as Bornstein, M., Jager, J., \& Steinberg, L. (2012); Gandhi, S. (2010); Bos, A.E.R., Muris, P., Mulkens, S., \& Schaalma, H.P. (2006).

The other two findings on good participants were broadly similar to those of satisfactory participants. They argue that instructors have a crucial role in making good learning designs and making classroom conditions more conducive to learning. Also, good participants did not 
seem sensitive to the learning approaches and methods. Based on the focus group discussion excerpt shown in Table 8, they can adapt and follow learning well regardless of the learning approach or method used by instructors.

\section{Discussion}

The results of the focus group discussion above illustrate some of the roles of instructors for prospective teachers. All participants as knowledge conveyors indeed reveal the vital role of instructors. However, this role seems gradual for each participant in a particular category.

Deficient participants rely heavily on instructors in playing their role in conveying knowledge. They prefer the direct learning model, which is interspersed with some intermezzo. This preference is supported by other studies (Andrews, 1984), which conclude that dependent students are outperformed independent students indirect or expository learning settings. How and why? Further research is needed on this phenomenon, especially in Indonesia. Nevertheless, we argue that Deficient Participants have wonted with the old-school learning method since they were in elementary or secondary school. As a result, it is difficult for them to accept new learning models.

Moreover, they cannot bear the demands in constructivist learning, which tend to be higher, with higher-order thinking goals. As Ausubel (1968) said, a full explanation at the beginning and then followed by examples can ease the thinking process. Interestingly, the participants expressed that they will be easier to understand when instructors provide examples, solutions, exercises and repeat them on the exam with the same difficulty level.

This opinion also reflects that they hardly appreciated the benefits of mathematics or its application to broader problems. Deficient Participants tend to think about completing the course and wish them luck to get high grades. It shows that they do not have confidence in their abilities. It is not surprising that there are only two things they expect from the instructors in fostering their mathematical disposition. First, by making the classroom more enjoyable so that it will foster their interest in the class. Second, encourage their persistence by guaranteeing that what they learn in class will appear on the test.

The role of instructors for participants in this study can be illustrated in Figure 1 below. The gray text indicates indicators of mathematical disposition that are slightly fostered by the roles they express. 


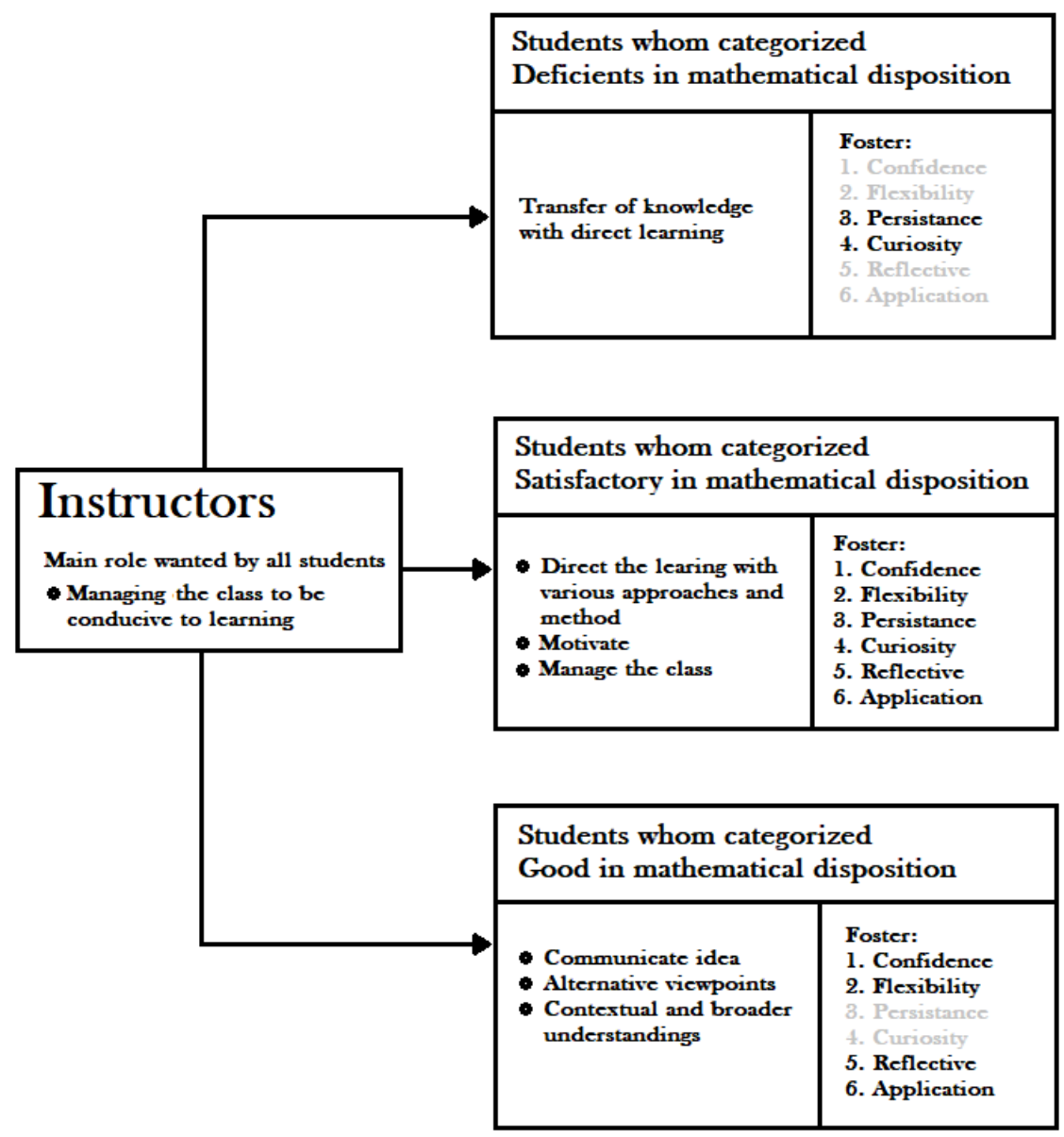

Figure 1. Instructors' role based on students' perspective

In Figure 1, we can see that instructors can foster Deficient Participants' persistence and curiosity but tend to be challenging to foster their confidence. That is because Deficient Participants have lost confidence in their abilities from the beginning. For them, self-confidence will only arise when they can solve problems. Even this will be difficult because the problems given must begin with the most basic. Deficient Participants are also not ready with diverse learning methods or different points of view, especially with the demands of higher-order thinking or contextual problems. We argue they need special treatment outside the regular class with the direct learning model.

For satisfactory participants, the role of instructors as sources of knowledge began to diminish slightly. Learning can be varied for them. Once the students are ready with various approaches and learning models, various demands, challenges, and new knowledge begin to open. With a varied approach and learning model, instructors can easily direct the learning to foster various expected abilities. However, participants still want instructors to manage the class well but do not view instructors as the primary source. Participants hand over the learning process to the instructors' approaches and methods. It characterizes that participants are ready 
to explore, analyze, test theorems, and follow the various challenges. In the excerpt from the focus group discussion results above, Satisfactory Participants hopes instructors have a suitable method in implementing learning and delivering a topic. They implied that the instructor's learning could provide flexibility and a different perspective on a problem for the participants.

Classroom learning for Good Participants is more suitable for learning management because they are easy to understand even with slight treatment. We argue that it is no longer a transfer of knowledge. Based on individual interviews and focus group discussions, Good Participants appear to be far more independent in learning than participants in other categories in this study. These results reinforce previous studies (AB, 2020; A.B. et al., 2019; Lin \& Tai, 2016; De Corte et al., 2000), stating that self-regulation learning is one of the main elements in developing mathematical disposition. Nevertheless, Good Participants still feel the need for classroom learning with direction from instructors. For them, the class becomes a selfactualization place to communicate their ideas, find alternatives and new perspectives.

In Figure 1, persistence and curiosity for Good Participants is in gray text, but it does not mean that they do not have persistence and curiosity. Even without any treatment, Good Participants naturally have their persistence and curiosity. They do not appear to need a boost of interest and persistence. Figure 1 illustrates that instructors can emphasize different aspects of students' mathematical dispositions. Based on the results obtained in this study, improperly emphasizing the learning process is said to have a slight impact on participants. Knowing the proper emphasis in developing the mathematical disposition will allow instructors to provide continuous treatment in learning. Therefore, a proper emphasis can provide continuous treatment on students, and as Buss \& Craik (1983) mentioned, continuous treatment will accelerate the efforts in fostering mathematical disposition.

\section{Conclusion}

The results obtained in this study indicate that the instructor's role is still needed in the classroom regardless of the students' mathematical disposition. Instructors for students who in this study are prospective teachers vary depending on their mathematical disposition. For prospective teachers who have an excellent mathematical disposition, the instructor's role is needed to confirm a theorem, confirm answers to questions, and the benefits of contextual topics. For prospective teachers who have a satisfactory mathematical disposition, the instructor's role is needed to motivate, direct the learning, and keep the classroom conductivity. Whereas for prospective teachers deficient in mathematical disposition, the instructor's role is 
needed as a direct learning source, structured learning director, and an enjoyable learning rhythm.

Nevertheless, there are similarities regarding an instructor's role from the perspective of prospective teachers, namely, relating to class management and interaction with students. These results are similar to other studies such as Gruber et al. (2010), which states that building an atmosphere of learning and interaction with students is an essential factor in learning. Meanwhile, in this study, class management and interaction with students can encourage curiosity, persistence. Even individual students can encourage their confidence.

Also, various approaches and methods such as student-centered learning begin to benefit students with a mathematical disposition in the satisfactory and good categories. The role of instructors in managing learning can be an excellent opportunity to use various methods that are under constructivist theory. According to Tam (2000), Honebein (1996), Brooks \& Brooks (1993) argue that constructivist classrooms can encourage the growth of several indicators such as those in mathematical disposition.

\section{References}

Ab, J. S. (2020). Self-regulated learning: Intelligence quotient and mathematical disposition. Journal of Physics: Conference Series, 1422(1), 012020. https://doi.org/10.1088/17426596/1422/1/012020.

Ab, J. S., Margono, G., \& Rahayu, W. (2019). The logical thinking ability: Mathematical disposition and self-regulated learning. Journal of Physics: Conference Series, 1155(1), 012092. https://doi.org/10.1088/1742-6596/1155/1/012092.

Andrews, J. D. (1984). Discovery and expository learning compared: Their effects on independent and dependent students. The Journal of Educational Research, 78(2), 80-89. https://doi.org/10.1080/00220671.1984.10885578.

Ausubel, D. P. (1968). Educational psychology: A cognitive view. New York: Holt, Rinehart \& Winston. https://doi.org/10.1080/00461526809528961.

Bornstein, M., Jager, J., \& Steinberg, L. (2012). Adolescents, parents, friends/peers: A relationships model (with commentary and illustrations). In I. Weiner, R. Lerner, M. Easterbrooks, \& J. Mistry (Eds.), Handbook of psychology: Vol. 6. Developmental psychology (2nd ed., pp. 393-433). New York, NY: Wiley.

Bos, A. E., Muris, P., Mulkens, S., \& Schaalma, H. P. (2006). Changing self-esteem in children and adolescents: A roadmap for future interventions. Netherlands Journal of Psychology, 62(1), 26-33. https://doi.org/10.1007/BF03061048.

Brooks, J., \& Brooks, M. (1993). In search of understanding: the case for constructivist classrooms, ASCD. NDT Resource Center database.

Buss, D. M., \& Craik, K. H. (1983). The act frequency approach to personality. Psychological Review, 90(2), 105. https://doi.org/10.1037/0033-295X.90.2.105.

Charmaz, K. (2006). Constructing grounded theory: A practical guide through qualitative analysis. London, UK: Sage Publications Inc. 
Collinson, V. (1996). Becoming an exemplary teacher: Integrating professional, interpersonal, and intrapersonal knowledge. Paper presented at The Annual Meeting of The JapanUnited States Teacher Education Consortium, Naruto, Japan.

Dale, C. (2010). Dispositions in Pre-service Teacher Preparation. Eastern Education Journal. 39(1). 3-12.

De Corte, E., Verschaffel, L., \& Op't Eynde, P. (2000). Self-regulation: A characteristic and a goal of mathematics education. In Handbook of self-regulation (pp. 687-726). https://doi.org/10.1016/B978-012109890-2/50050-0.

Froyd, J., \& Simpson, N. (2008, August). Student-centered learning addressing faculty questions about student-centered learning. In Course, Curriculum, Labor, and Improvement Conference, Washington DC (Vol. 30, No. 11, pp. 1-11).

Gandhi, S. (2010). Self-Confidence - An Asset to All Humans. Journal of School Social Work, 6(11), 8-10.

Glaser, B. G. (1978). Theoretical sensitivity. Mill Valley, CA, USA: Sociology Press.

Glaser, B. G. (1992). Discovery of grounded theory. Chicago, IL, USA: Aldine.

Glaser, B. G., \& Strauss, A. L. (1967). The discovery of grounded theory: Strategies for qualitative research. Aldine Transaction: A Division of Transaction Publishers, New Brunswick, NJ, USA.

Gruber, T., Reppel, A., \& Voss, R. (2010). Understanding the characteristics of effective professors: The student's perspective. Journal of Marketing for Higher Education, 20(2), 175-190. https://doi.org/10.1080/08841241.2010.526356.

Handelsman, J., Ebert-May, D., Beichner, R., Bruns, P., Chang, A., DeHaan, R., ... \& Wood, W. B. (2004). Scientific teaching. Science, 304(5670), 521-522. https://doi.org/10.1126/science.1096022.

Harel, G. (2008a). What is mathematics? A pedagogical answer to a philosophical question. Proof and other dilemmas: Mathematics and philosophy, ZDM, 265-290.

Harel, G. (2008b). DNR perspective on mathematics curriculum and instruction, Part I: focus on proving. ZDM, 40(3), 487-500. https://doi.org/10.1007/s11858-008-0104-1.

Honebein, P. C. (1996). Seven goals for the design of constructivist learning environments. Constructivist learning environments: Case studies in instructional design, 11-24.

Katz, L. \& Raths, J. (1986). Dispositional goals for teacher education: Problems of identification and assessment. Paper presented at The Twenty-third World Assembly of the International Council on Education for Teaching, Kingston, Jamaica.

Knodel, J. (1993). The design and analysis of focus group studies: A practical approach. In D. Morgan (Ed.), Successful focus groups: Advancing the state of the art (pp. 35-50). Thousand Oaks, CA: Sage. https://doi.org/10.4135/9781483349008.n3.

Leech, N. L., \& Onwuegbuzie, A. J. (2007). An array of qualitative data analysis tools: A call for data analysis triangulation. School Psychology Quarterly, 22, 557- 584. https://doi.org/10.1037/1045-3830.22.4.557.

Leech, N. L., \& Onwuegbuzie, A. J. (2008). Qualitative data analysis: A compendium of techniques and a framework for selection for school psychology research and beyond. School Psychology Quarterly, 23, 587-604. https://doi.org/10.1037/1045-3830.23.4.587.

Lin, S. W., \& Tai, W. C. (2016). A longitudinal study for types and changes of students' mathematical disposition. Universal Journal of Educational Research, 4(8), 1903-1911. https://doi.org/10.13189/ujer.2016.040821.

Maass, K., Geiger, V., Ariza, M. R., \& Goos, M. (2019). The role of mathematics in interdisciplinary STEM education. ZDM, 51, 869-884. https://doi.org/10.1007/s11858019-01100-5.

Mahoney, T. B., \& Choe, S. T. (2016). Understanding students is the key to be a good professor. Journal of Higher Education Theory and Practice, 16(1). 
McCombs, B., \& Whistler, J. (1997). The learner-centered school: Strategies for increasing student motivation and achievement. In B.L. McCombs \& J.S. Whistler (Eds.), The learner-centered classroom (pp. 63-101). San Francisco: Jossey-Bass.

Morgan, D. (1998). Planning focus groups. Thousand Oaks, CA: Sage. https://doi.org/10.4135/9781483328171.

Morgan, D. L. (1988). Focus group as qualitative research. Newbury Park, CA: Sage Publications Inc.

National Council of Teachers of Mathematics. (1989). Curriculum and evaluation standards for School Mathematics. Reston, VA: The NCTM.

National Council of Teachers of Mathematics. (2000). Principles and standards for school mathematics. Reston, VA: The NCTM.

Osguthorpe, R. (2008). For the reasons, we want teachers of good disposition and moral character. Journal of Teacher Education, 59(4), 288-299. https://doi.org/10.1177/0022487108321377.

Robson, C. (2006). How to do a research project: a guide for undergraduate students. Malden, MA: Blackwell Pub.

Strauss, A. L. (1987). Qualitative analysis for social scientists. Cambridge, UK: Cambridge University Press. https://doi.org/10.1017/CBO9780511557842.

Tam, M. (2000). Constructivism, instructional design, and technology: Implications for transforming distance learning. Educational Technology and Society, 3(2).

TEAL. (2010). TEAL Center fact sheet \#2: Universal design for learning. Teaching Excellence in Adult Literacy Center. American Institutes for Research.

Yin, R. (1989). Case study research: Design and methods, 2nd ed. London, UK: Sage Publications Inc. 